\title{
Thermal Analysis of Methanol Reforming Proton Exchange Membrane
}

\section{Fuel Cell System}

\author{
Jialin Zhao ${ }^{1}$, Yongwen Yang ${ }^{1}$, Hong Yang ${ }^{2}$, Yanan Li ${ }^{3}$,Guihai Jiao ${ }^{1}$,Lei \\ Zhang $^{1}$, Jingjing $X u^{1}$ \\ ${ }^{1}$ College of energy and Mechanical Engineering, Shanghai University of Electric Power, China \\ ${ }^{2}$ China Guodian Yuyuan Power Generation Co., Ltd, China \\ ${ }^{3}$ China Huaneng Yuhuan Power Generation Co., Ltd, China
}

\begin{abstract}
KEYWORD:Methanol reforming hydrogen production, Proton exchange membrane Fuel Cell, Waste heat analysis, system optimization.

ABSTRACT:Relatively mature methanol reforming PEMFC products have been produced domestically, and power generation efficiency of the whole system can reach $30 \%$, but most of the waste heat is not used. Based on an experiment table of methanol reforming PEMFC system, a large mount of data about the internal temperature, pressure, electric current, voltage of the whole system running under different output power is collected, and the actual waste heat generated by the system at different output power is calculated. Then the theoretical calculation of waste heat is compared with the actual value of waste heat of the system. The direction of waste heat utilization and optimization of the whole system is proposed.
\end{abstract}

\section{RESEARCH BACKGROUND}

Proton exchange membrane fuel cell (PEMFC) is currently the most mature fuel cell, has a wide application in power, mobile power, distributed power and power in the family vehicle[1]. In actual operation, some directly use a hydrogen storage tank to provide hydrogen fuel for the cell stack, some use reformer system to reform natural gas, methanol or other fuels into hydrogen. The way of getting hydrogen by methanol reforming has many features such as better economy, low power consumption, low reforming temperature (about $300^{\circ} \mathrm{C}$ ), easy to store and transport, convenient and safety to charge fuel and so on. Because of these futures, methanol reforming is attracting more and more attention[2].

Barelli et al. [3] simulated and compared kilowatt cogeneration systems with ASPEN, which are based on SOFC and low-temperature PEMFC. The results show that PEMFC cogeneration system working at a state of low temperature and atmospheric pressure is a more efficient system, tough the power generation efficiency of SOFC(40\%) is slightly higher than the power generation efficiency of low-temperature PEMFC(up to 32\%). PEMFC cogeneration system is still the first choice for residents. Borja et al.[4] developed thermodynamics, geometry and economic models, which can be used for multi-unit housing and multi-generation proton exchange membrane fuel cell system. The results obtained by using the above models show that the power generation efficiency in the synthesis/design point reaches $39 \%$, and the efficiency of cogeneration reaches $72 \%$.

China now has more mature methanol reforming proton exchange membrane fuel cell products, the power generation efficiency of these systems are around 30\%, but the aspect of the waste heat utilization of system does not attract enough attention, there is a large room for improvement for the overall efficiency of the system. In academic research, there are more simulations about internal 
heat conduction of the fuel cell stacks and cooling of systems, but relatively less researches on fuel cell cogeneration systems. There are more literatures about simulating systems by using software, but relatively less researches on the actual operation of systems. There are more researches about fuel cells using direct hydrogen source, but relatively less literatures considering the heat of the fuel reforming part.

\section{RESEARCH OBJECT}

The methanol reforming proton exchange membrane fuel cell system test bench in Shanghai university of electric power is shown as Fig.1, DC voltage $48 \mathrm{~V}$ and rated power $5 \mathrm{~kW}$ can be outputted together with the external battery on the test bench. The temperature, pressure, voltage, current and other parameters of the methanol fuel cell can be monitored on the test bench, in addition, multiplex numerical values and analog control signals can be outputted on the test bench.

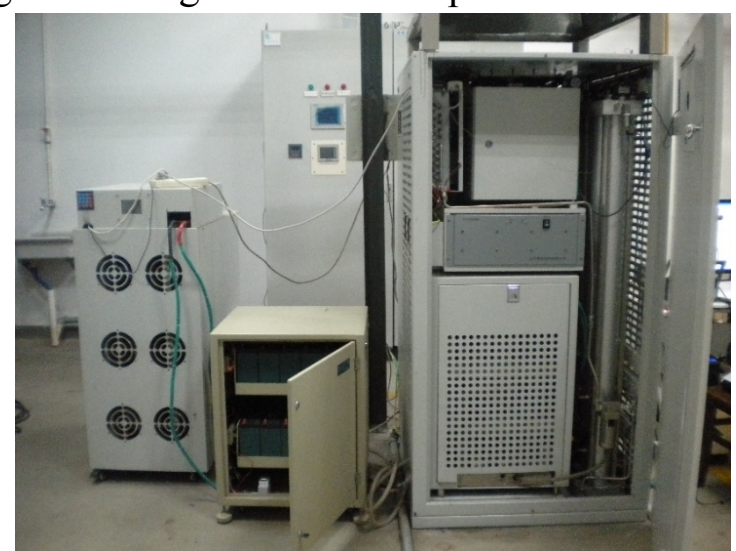

Fig.1.The methanol reforming PEMFC system bench

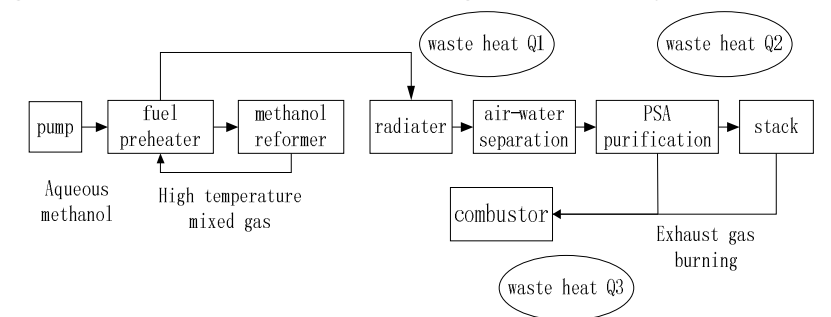

Fig.2. The flow chart of methanol reforming PEMFC system

Flow chart of the methanol reforming PEMFC system is shown as Fig. 2, the fuel in the system is aqueous methanol with the molar ratio of $1: 1.5$, which is converted to hydrogen mixed gas, and the running temperature in the upper of methanol reformer is $280 \sim 400^{\circ} \mathrm{C}$. The mixed gas first preheats the fuel in the fuel preheater, then is cooled in the radiator, after water-gas separation and purification of PSA, high purity hydrogen is separated. At last, electrochemical reaction with the hydrogen is happened in the fuel cell stack, producing the direct current, which is converted into alternating current in the DC-AC converter and is provided to outside users. Surplus combustible gases are mainly produced during the PSA purification process: In order to ensure the activity of molecular sieve adsorbents, hydrogen is needed to rinse molecular sieve for the completion of adsorbent regeneration. The efficiency of hydrogen purification of PSA in the test bench is about $60 \%$. Water-cooled and air-cooled are used in the cooling system, and heat is dissipated to the outside without utilization. In general, the energy efficiency of the system is very low.

As it can be seen from the Fig. 2, there is three major heat loss in the system: heat dissipation in the radiator $\mathrm{Q}_{1}$, waste heat generated during the operation of the stack $\mathrm{Q}_{2}$ and the waste heat produced from the exhaust gas combustion $\mathrm{Q}_{3}$.So, the waste heat available in the system can be expressed as Formula 1: 


$$
Q_{w}=\sum_{\mathrm{i}=1}^{3} \mathrm{Q}_{\mathrm{i}}
$$

The purpose of this paper is to examine the waste heat of the various parts in the system at different output power. Various output power of the system is set from $1000 \mathrm{~W}$ to $5000 \mathrm{~W}$, and keep the equipment operating smoothly for a period of time under different power. Stack current, voltage, methanol fuel flow, inlet and outlet temperature difference and other data are recorded every three seconds. Finally, the data is processed to obtain the waste heat of each part and the waste heat is compared with the theoretical heat.

\section{THERMAL ANALYSIS OF THE SYSTEM}

\section{Theoretical Foundation}

In order to calculate waste heat of every module in the system during the operation, there is need to use the original data includes generating power of the fuel cell stack, current, voltage, flow of methanol fuel, outflow temperature of reformer, outflow temperature of the preheater, outflow temperature of the radiator and so on. Due to technical reasons, the real-time flow data of hydrogen can't be obtained, so in order to accurately calculate the hydrogen consumption data and other data, the following concepts and formulas will be needed.

(1)The theoretical hydrogen consumption $\quad n_{H_{2}}=\frac{I}{2 F}$

Here, $n_{H_{2}}$ is the supply of hydrogen fuel per unit time, the unit mol / s. $I$ is the fuel cell stack current, $F$ is Faraday constant, usually, $F=96485.3365 \mathrm{C} / \mathrm{mol}$.

(2) The waste heat generated by PEMFC

In the case of the known actual voltage and current, according to the difference between the theoretical open circuit voltage and the actual voltage of the stack, heat generated by the proton exchange membrane fuel cell can be calculated as fomular (3):

$$
Q_{2}=\left(V_{\text {ocv }}-V_{\text {cell }}\right) \cdot I \cdot n_{\text {cell }} \cdot 3.6
$$

Here, $V_{\text {cell }}$ and I are the output voltage and current of monolithic fuel cell respectively, $n_{\text {cell }}$ is the number of pieces in the fuel cell stack. In this paper, $V_{o c v}$ is reversible open circuit voltage of hydrogen fuel cell (volts). $V_{o c v}=1.23 \mathrm{~V}, n_{\text {cell }}=80$.

(3) Fuel cell efficiency

$$
\eta=\frac{\text { energy released by } 1 \text { mol juel }}{-\Delta H}
$$

Here, $-\Delta H$ is the high calorific value of Hydrogen combustion, $285.84 \mathrm{~kJ} / \mathrm{mol}$. It is noteworthy that the fuel cell power generation efficiency here is power generation efficiency of the fuel cell stack itself, not power generation efficiency of the system.

(4) Methanol steam reforming reaction

Primary reaction:

$\mathrm{CH}_{3} \mathrm{OH}+\mathrm{H}_{2} \mathrm{O} \rightarrow 3 \mathrm{H}_{2}+\mathrm{CO}_{2} \Delta \mathrm{H}_{298}=49.4 \mathrm{~kJ} / \mathrm{mol}$ (5)

Side reaction:

$\begin{array}{lc}\mathrm{CH}_{3} \mathrm{OH} \rightarrow \mathrm{CO}+2 \mathrm{H}_{2} & \Delta \mathrm{H}_{298}=90.7 \mathrm{~kJ} / \mathrm{mol} \\ 2 \mathrm{CH}_{3} \mathrm{OH} \rightarrow \mathrm{CH}_{3} \mathrm{OCH}_{3}+\mathrm{H}_{2} \mathrm{O} \Delta \mathrm{H}_{298}=-24.9 \mathrm{~kJ} / \mathrm{mol} \\ \mathrm{CO}+3 \mathrm{H}_{2} \rightarrow \mathrm{CH}_{4}+\mathrm{H}_{2} \mathrm{O} \quad \Delta \mathrm{H}_{298}=-206.3 \mathrm{~kJ} / \mathrm{mol}\end{array}$ 
(5) Heat loss of the hot mixed gas in the radiator is equal to the energy difference between internal energy of the inlet and internal energy of the outlet:

$$
Q_{1}=E_{\text {out }}-E_{\text {in }}
$$

The total internal energy of per unit mass of the gas mixture can be expressed as fomular(7):

$$
E=m_{\mathrm{CO} 2} \cdot e_{\mathrm{CO} 2}+m_{\mathrm{H} 2} \cdot e_{\mathrm{H} 2}+m_{\mathrm{H} 2 \mathrm{O}} \cdot e_{\mathrm{H} 2 \mathrm{O}}
$$

\section{The actual waste heat condition of system}

\section{Waste heat of the radiator Q1}

High temperature and high pressure mixture gas was generated when methanol reformer is operating under actual conditions. In addition to the $\mathrm{H}_{2}, \mathrm{CO}_{2}$ and water vapor, the mixture gas also contains trace amounts of $\mathrm{CO}, \mathrm{CH}_{3} \mathrm{OCH}_{3}$ and $\mathrm{CH}_{4}$ and other imp-

Table 1. In the methanol reforming module, the temperature of the radiator's inflow and outflow

\begin{tabular}{cccc}
\multicolumn{4}{c}{ measured under different stack power } \\
\hline $\begin{array}{c}\text { Actual } \\
\text { average } \\
\text { power } \\
/ \mathrm{W}\end{array}$ & $\begin{array}{c}\text { Methanol } \\
\text { aqueous } \\
\text { flow } \\
/ \mathrm{kg} \cdot \mathrm{h}-1\end{array}$ & $\begin{array}{c}\text { Radiator } \\
\text { inflow } \\
\text { temperature } \\
/{ }^{\circ} \mathrm{C}\end{array}$ & $\begin{array}{l}\text { Radiator } \\
\text { outflow } \\
\text { temperature } \\
/{ }^{\circ} \mathrm{C}\end{array}$ \\
\hline 1.28 & 1.81 & 80.42 & 26.87 \\
1.70 & 2.38 & 84.99 & 22.25 \\
2.13 & 2.35 & 87.31 & 21.34 \\
2.56 & 2.66 & 95.06 & 25.45 \\
3.10 & 3.07 & 103.49 & 26.1 \\
3.68 & 3.50 & 112.01 & 27.82 \\
3.78 & 3.62 & 115.15 & 28.37 \\
4.31 & 4.21 & 116.13 & 30.91 \\
5.35 & 5.30 & 125.81 & 30.13 \\
\hline
\end{tabular}

urities. These impurities are negligible in the calculation of the mixed gas's internal energy, so mass fraction of each component in the mixed gas is: $\omega(\mathrm{CO} 2)=74.58 \%, \omega(\mathrm{H} 2)=10.17 \%$, $\omega(\mathrm{H} 2 \mathrm{O})=15.25 \%$.

As shown in Table 1, when experiment runs at different power, in the methanol reforming module, the temperature of the radiator's inflow and outflow is measured by temperature sensor.

Take $1.28 \mathrm{~kW}$ as an example to calculate the waste heat $\mathrm{Q}_{1}$ of radiator:the actual average output power of stack is $1281.9 \mathrm{~W}$, the measured average mass flow of aqueous methanol solution is $\dot{m}=1.81 \mathrm{~kg} / \mathrm{h}$. the measured average temperature of the mixture gas out of fuel preheater is $80.42^{\circ} \mathrm{C}$, the measured average temperature of radiator outflow is $26.87^{\circ} \mathrm{C}$.

The waste heat of the mixture gas $\mathrm{Q}_{1}$ through the radiator can be calculated by combining with Formula (6), (7): 
$Q_{1}=E_{\text {out }}-E_{\text {in }}$

$=\dot{m} \cdot \omega_{\mathrm{CO}_{2}} \cdot\left(e_{\mathrm{CO}_{2}, 80.42 \mathrm{C}}-e_{\mathrm{CO}_{2}, 26.87 \mathrm{C}}\right)$

$+\dot{m} \cdot \omega_{H_{2}} \cdot\left(e_{H_{2}, 80.42^{\circ} \mathrm{C}}-e_{H_{2}, 26.87^{\circ} \mathrm{C}}\right)$

$+\dot{m} \cdot \omega_{\mathrm{H}_{2} \mathrm{O}} \cdot\left(e_{\mathrm{H}_{2} \mathrm{O}, 80.42 \mathrm{C}}-e_{\mathrm{H}_{2} \mathrm{O}, 26.87 \mathrm{C}}\right)$

$=213.10 \mathrm{~kJ} / \mathrm{h}$

Here, internal energy of the components $\left(\mathrm{H}_{2}, \mathrm{CO}_{2}\right.$ and $\left.\mathrm{H}_{2} \mathrm{O}\right)$ of the mixture gas at different temperature can be obtained by handbook of Chemistry[5].

Other waste heat of radiator $\mathrm{Q}_{1}$ under other power can be calculated in the same way, and the result is shown in Table 2. In order to see the trend of the waste heat of radiator $\mathrm{Q}_{1}$ under actual stack generation power, you can see Fig.3.

Table2 The waste heat $\mathrm{Q}_{1}$ under different stack output power

\begin{tabular}{cc}
\hline $\begin{array}{c}\text { Actual average pow- } \\
\text { er } / \mathrm{W}\end{array}$ & $\begin{array}{c}\text { Radiator waste heat } \\
\mathrm{Q}_{1} / \mathrm{kJ} \cdot \mathrm{h}-1\end{array}$ \\
\hline 1281.89 & 213.10 \\
1697.87 & 329.12 \\
2125.94 & 340.90 \\
2556.37 & 409.42 \\
3099.60 & 526.15 \\
3684.48 & 652.51 \\
3781.17 & 697.42 \\
4314.87 & 796.99 \\
5350.25 & 1126.18 \\
\hline
\end{tabular}

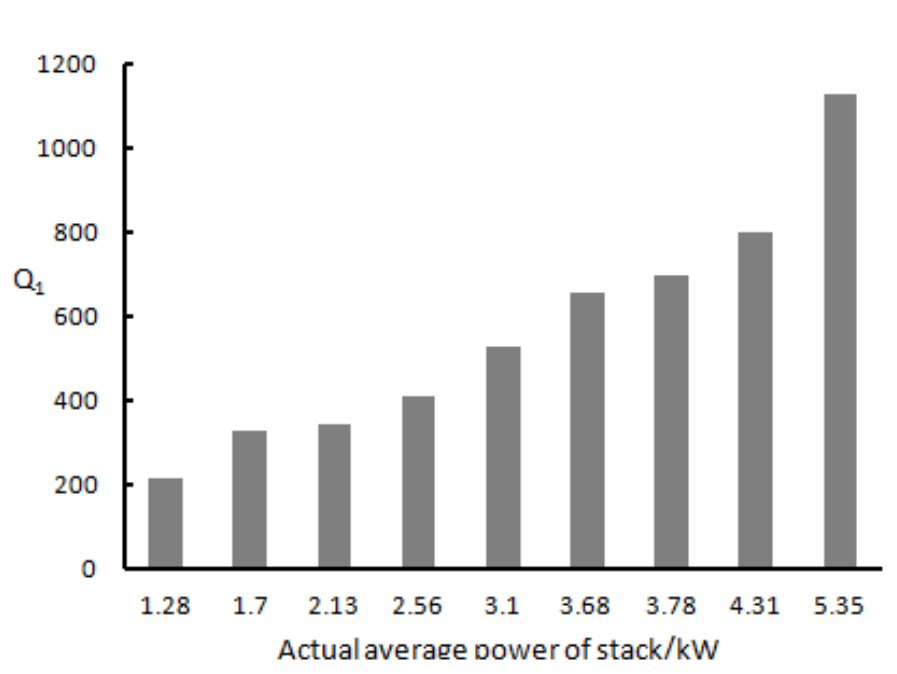

Fig.3. The waste heat of radiator $\mathrm{Q}_{1}$ under different power

As shown in Fig.3, with the increase of power, the waste heat of radiator $\mathrm{Q}_{1}$ is increasing regularly.

\section{Waste heat of the fuel cell stack,Q2}

$\mathrm{Q}_{2}$ generated by PEMFC can be calculated by Formula (3) according to the difference between the theory voltage and actual voltage of stack; Hydrogen consumption in stack was calculated by Formula (2). The power generation efficiency of the stack can be calculated by Formula (4), the specific calculation process as follow. The current, voltage, and other parameters of the stack measured under different output power was shown in Table 3, which was substituted into Formula (3) to calculate the calorific value of stack, $\mathrm{Q}_{2}$. 
Table 3 The parameters of the stack under different power

\begin{tabular}{cccc}
\hline $\begin{array}{c}\text { Average output } \\
\text { power /W }\end{array}$ & $\begin{array}{c}\text { Average output } \\
\text { current /A }\end{array}$ & $\begin{array}{c}\text { Average output } \\
\text { voltage /V }\end{array}$ & $\begin{array}{c}\text { Monolithic fuel cell } \\
\text { voltage/V }\end{array}$ \\
\hline 1281.89 & 20.04 & 63.97 & 0.800 \\
1697.87 & 26.98 & 62.99 & 0.787 \\
2125.94 & 35.18 & 60.44 & 0.755 \\
2556.37 & 42.66 & 59.93 & 0.749 \\
3099.60 & 52.21 & 59.37 & 0.742 \\
3684.48 & 61.81 & 59.62 & 0.7452 \\
3781.17 & 63.37 & 59.66 & 0.746 \\
4314.87 & 75.05 & 57.48 & 0.719 \\
5350.25 & 93.81 & 57.05 & 0.713 \\
\hline
\end{tabular}

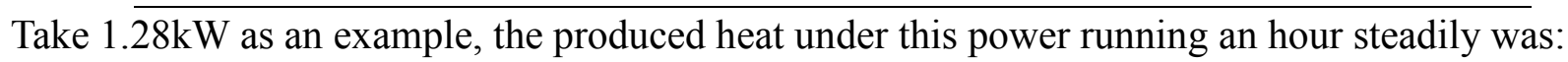

$Q_{2}=\left(V_{\text {ocv }}-V_{\text {cell }}\right) \cdot I \cdot n_{\text {cell }} \cdot 3600$

$=(1.23 \mathrm{~V}-0.80 \mathrm{~V}) \times 20.04 \mathrm{~A} \times 80 \times 3600 \mathrm{~s}$

$=2484.3 \mathrm{~kJ}$

Hydrogen consumption in stack:

$n_{\mathrm{H}_{2}}=I / 2 \mathrm{~F}$

$=20.04 \mathrm{~A} \div(2 \times 96485.3 \mathrm{c} / \mathrm{mol}) \times 3600 \times 80$

$=29.91 \mathrm{~mol} / \mathrm{h}$

The power generation efficiency of the stack:

$\eta=\frac{\text { Power generation capacity }}{-\Delta H}$

$=\frac{1281.89 \mathrm{~W} \times 3600 \mathrm{~s}}{285.84 \mathrm{~kJ} / \mathrm{mol} \times 29.91 \mathrm{~mol}}$

$=54.2 \%$

The waste heat of stack $\mathrm{Q}_{2}$ and power generation efficiency of stack under other power was also calculated as above. The result was shown inTable4.

Table 4 The waste heat of stack $\mathrm{Q}_{2}$ under different power.

\begin{tabular}{cccc}
\hline $\begin{array}{c}\text { Average output } \\
\text { power/W }\end{array}$ & $\begin{array}{c}\text { Hydrogen consump- } \\
\text { tion } /(\mathrm{mol} \cdot \mathrm{h}-1)\end{array}$ & $\begin{array}{c}\text { Waste heat of stack } \\
\left.\mathrm{Q}_{2} / \mathrm{kJ} \cdot \mathrm{h}-1\right)\end{array}$ & $\begin{array}{c}\text { Power generation efficiency } \\
\text { of stack } / \%\end{array}$ \\
\hline 1281.89 & 29.91 & 2484.26 & 54.20 \\
1697.87 & 40.23 & 3436.93 & 53.36 \\
2125.94 & 52.50 & 4807.69 & 51.20 \\
2556.37 & 63.66 & 5907.75 & 50.77 \\
3099.60 & 77.92 & 7336.17 & 50.30 \\
3684.48 & 92.25 & 8629.44 & 50.51 \\
3781.17 & 94.58 & 8837.44 & 50.55 \\
4314.87 & 112.01 & 11054.7 & 48.71 \\
5350.25 & 140.00 & 13962.5 & 48.32 \\
\hline
\end{tabular}




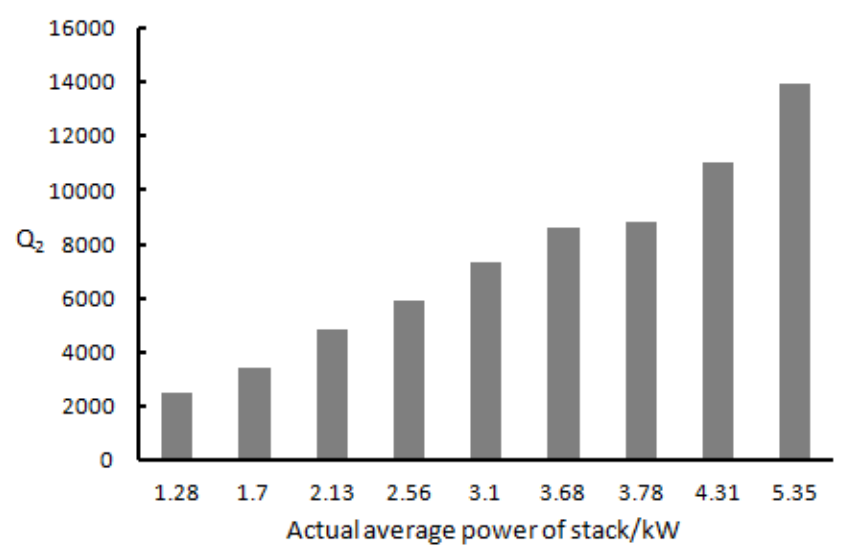

Fig.4 The waste heat of stack $\mathrm{Q}_{2}$ under different power

The waste heat, $\mathrm{Q}_{2}$, under different power was shown in Fig.4. From Fig.4, we can see that $\mathrm{Q}_{2}$ increases with the increasing of power of the stack.

\section{Waste heat of residual gas combustion, Q3}

In the case of the output power of $1.28 \mathrm{~kW}$, Table 4 shows that the amount of hydrogen consumption of the fuel cell stack is $29.91 \mathrm{~mol} / \mathrm{h}$, and the actually measured flow rate of methanol consumption is $30.65 \mathrm{~mol} / \mathrm{h}$. The fully capable of producing hydrogen reaction is $91.95 \mathrm{~mol} / \mathrm{h}$ by methanol reforming expression. The waste heat $\mathrm{Q}_{3}$ generated from the burning of residual gas burning is equal to the heat of hydrogen combustion minus the heat absorption of remaining methanol reforming reaction. Here, the combustion heat of hydrogen is low calorific value:

$Q_{3}=(91.95-29.91) \mathrm{mol} \times 241.83 \mathrm{~kJ} / \mathrm{mol}$

$-30.65 \mathrm{~mol} \times 49.4 \mathrm{~kJ} / \mathrm{mol}$

$=13489.02 \mathrm{~kJ}$

The purification efficiency of PSA: $\eta_{P S A}=29.91 \div 91.95=32.53 \%$

The waste heat $\mathrm{Q}_{3}$ and the purification efficiency of PSA under different output power will be respectively calculated as shown in Table 5 .

Table 5 Waste heat Q3 under different output power

\begin{tabular}{cccccc}
\hline $\begin{array}{c}\text { Power of } \\
\text { stack/W }\end{array}$ & $\begin{array}{c}\text { Flow rate of } \\
\text { methanol } \\
/\left(\mathrm{mol} \cdot \mathrm{h}^{-1}\right)\end{array}$ & $\begin{array}{c}\mathrm{H} 2 \text { production } \\
\text { of methanol } \\
/\left(\mathrm{mol} \cdot \mathrm{h}^{-1}\right)\end{array}$ & $\begin{array}{c}\mathrm{H} 2 \text { consumption of } \\
\text { stack } /\left(\mathrm{mol} \cdot \mathrm{h}^{-1}\right)\end{array}$ & $\begin{array}{c}\text { Purification } \\
\text { efficiency of } \\
\mathrm{PSA} / \%\end{array}$ & $\begin{array}{c}\text { Waste heat of } \\
\text { remaining gas } \\
\mathrm{Q}_{3} / \mathrm{kJ}\end{array}$ \\
\hline 1281.89 & 30.65 & 91.95 & 29.91 & 32.53 & 13489.85 \\
1697.87 & 40.38 & 121.15 & 40.23 & 33.21 & 17573.66 \\
2125.94 & 39.78 & 119.35 & 52.50 & 43.99 & 14201.91 \\
2556.37 & 45.16 & 135.49 & 63.66 & 46.99 & 15137.76 \\
3099.60 & 52.10 & 156.29 & 77.92 & 49.86 & 16378.04 \\
3684.48 & 59.29 & 177.88 & 92.25 & 51.86 & 17780.38 \\
3781.17 & 61.40 & 184.21 & 94.58 & 51.35 & 18640.07 \\
4314.87 & 71.41 & 214.22 & 112.01 & 52.29 & 21190.02 \\
5350.25 & 89.75 & 269.24 & 140.00 & 52.00 & 26819.07 \\
\hline
\end{tabular}




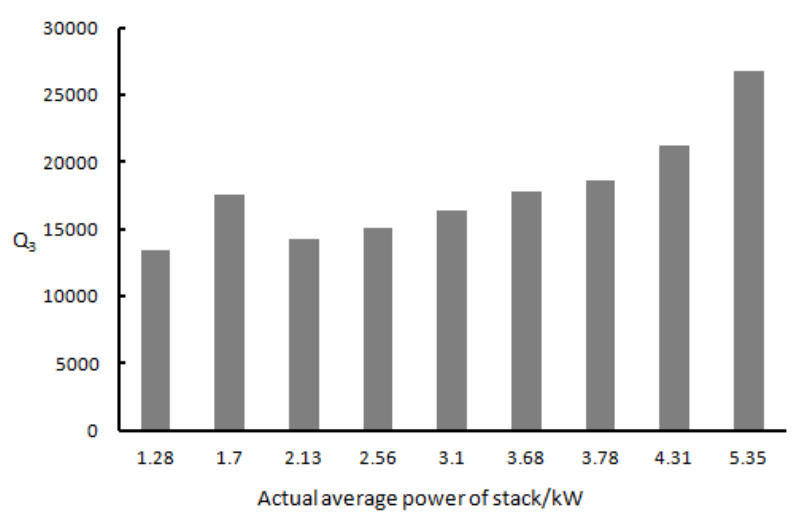

Fig.5. Waste heat of remaining gas $\mathrm{Q}_{3}$ under different power

As shown in Fig.5, the waste heat $\mathrm{Q}_{3}$ increases with the increase of the output power of electric stack. $Q_{3}$ will reaches $26819 \mathrm{~kJ} / \mathrm{h}$ when output power of electric stack reaches $5.35 \mathrm{~kW}$, which causes wastage of system energy.

\section{Analysis of waste heat of the system}

Still in the case of the output power of $1.28 \mathrm{~kW}$, the equipment consumes 30.65 mol methanol for running an hour, as we all know, low calorific value of methanol is $724.738 \mathrm{~kJ} / \mathrm{mol}$, so the chemical energy entering the whole system is $22268.34 \mathrm{~kJ}$.

Power generation efficiency of the system:

$\eta_{s y s}=\frac{\text { Power generation of the system }}{\text { The chemical energyentering the system }}$

$=\frac{1282.89 \mathrm{~W} \times 3.6}{30.65 \mathrm{~mol} \times 724.738 \mathrm{~kJ} / \mathrm{mol}} \times 100 \%$

$=20.72 \%$

$\mathrm{Q}_{1} 、 \mathrm{Q}_{2}$ and $\mathrm{Q}_{3}$ add up to the total waste heat, $\mathrm{Q}_{\mathrm{w}}$, its value is $16187.21 \mathrm{~kJ}$, which accounts for $72.87 \%$ of total chemical energy of the system.

As shown in Table6, power generation efficiency of the system under different output power of stack is calculated .In addition, the overall power generation efficiency of the system $\left(\eta_{\text {sys }}\right)$ and the waste heat efficiency of the system $\left(\eta_{\mathrm{w}}\right)$ are calculated in Table6.

The percentage of the three parts of waste heat under different power system of total waste heat situation is shown in Fig.6, the waste heat $\mathrm{Q}_{3}$ from the burning of the remaining gas occupy a large part, which is due to low purification efficiency of the process of PSA purification. And the waste heat Q1 from radiator accounts for a small proportion of total waste heat, because the high temperature and high pressure gas out of the reformer first preheats the fuel in the preheater, when the gas arrives in radiator, its temperature has dropped to $80 \sim 120^{\circ} \mathrm{C}$ and it has a low heat quality. 
Table 6 Waste heat under different output power of stack

\begin{tabular}{ccccccccc}
\hline $\begin{array}{c}\text { Average } \\
\text { output } \\
\text { power of } \\
\text { stack } / \mathrm{W}\end{array}$ & $\mathrm{Q}_{1} / \mathrm{kJ}$ & $\mathrm{Q}_{2} / \mathrm{kJ}$ & $\mathrm{Q}_{3} / \mathrm{kJ}$ & $\mathrm{Q}_{\mathrm{w}} / \mathrm{kJ}$ & $\begin{array}{c}\text { The chemical } \\
\text { energy enter- } \\
\text { ing the sys- } \\
\text { tem } / \mathrm{kJ}\end{array}$ & $\eta_{\text {sys }} / \%$ & $\eta_{\mathrm{w}} / \%$ & $\begin{array}{c}\text { Waste } \\
\text { heat effi- } \\
\text { ciency of } \\
\text { theory } / \%\end{array}$ \\
\hline 1281.89 & 213.1 & 2484.26 & 13489.85 & 16187.21 & 22212.74 & 20.72 & 72.87 & \\
1697.87 & 329.12 & 3436.93 & 17573.66 & 21339.71 & 29266.41 & 20.84 & 72.92 & \\
2125.94 & 340.9 & 4807.69 & 14201.91 & 19350.50 & 28831.91 & 26.48 & 67.11 & \\
2556.37 & 409.42 & 5907.75 & 15137.76 & 21454.93 & 32728.78 & 28.05 & 65.55 & \\
3099.60 & 526.15 & 7336.17 & 16378.04 & 24240.36 & 37754.48 & 29.48 & 64.21 & 69.6 \\
3684.48 & 652.51 & 8629.44 & 17780.38 & 27062.33 & 42970.44 & 30.79 & 62.98 & \\
3781.17 & 697.42 & 8837.44 & 18640.07 & 28174.93 & 44498.03 & 30.52 & 63.32 & \\
4314.87 & 796.99 & 11054.7 & 21190.02 & 33041.71 & 51747.44 & 29.94 & 63.85 & \\
5350.25 & 1126.18 & 13962.5 & 26819.07 & 41907.75 & 65038.29 & 29.54 & 64.44 & \\
\hline
\end{tabular}

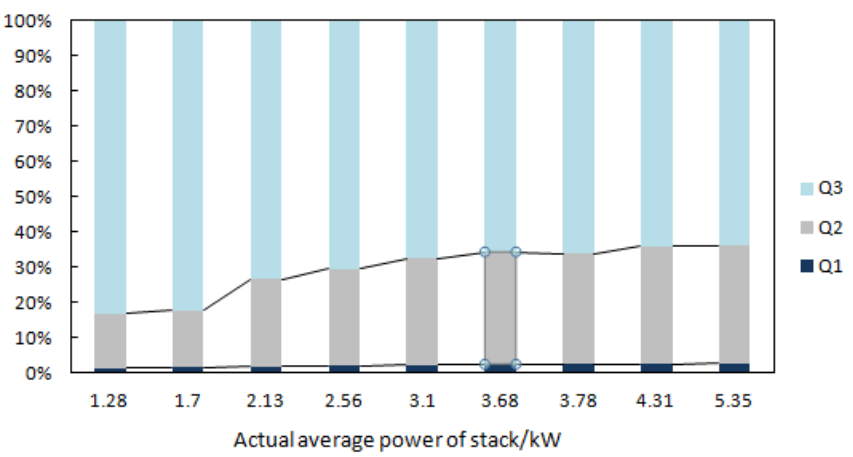

Fig.6. The percentage bar charts of system's waste heat

\section{CONCLUSION}

1) The results show that with the increase of cell stack output power, waste heat of system increases significantly, but its proportion accounting for chemical energy of the entire system decreased from $72.87 \%$ to $64.44 \%$.

2) To ensure the purity of hydrogen, a certain amount of hydrogen is needed to rinse molecular sieve in the process of PSA purification, the efficiency of PSA purification increases with the increasing flow of methanol determined by cell stack power. PSA purification efficiency is only $32.53 \%$ in the case of $1 \mathrm{~kW}$ power, while it can reach $52 \%$ in the case of $5 \mathrm{~kW}$ power.

3) The waste heat $\mathrm{Q}_{3}$ from the residual gas combustion accounts for the largest proportion of the overall system, it reaches more than $64 \%$ of the total waste heat and more than $30 \%$ of chemical energy. The main reason is related to the efficiency of molecular sieve. In the optimizing the efficiency of the system, higher purification efficiency of PSA systems should be considered, in addition, attention should be focused on the use of waste heat $\mathrm{Q}_{3}$ generated by the residual gas combustion.

4) These three part waste heat are not all the waste heat, in addition, a little waste heat lost in the air through the surface of the device.

\section{REFERENCES}

[1] Bao lian Yi. fuel cell: Principles - Technology • Applications [M] Beijing: Chemical Industry Press, 2003: 23-24

[2] George A. Olah\& Alain Goeppert\& G.K. Surya Prakash. Beyond Oil and Gas: The Methanol Economy[M]. Publisher: Wiley-VCH, 2006-03-23 
[3] Barelli L\& Bidini G\& Gallorini F, et al. An energetic-exergetic comparison between PEMFC and SOFC-based micro-CHP systems[J]. International Journal of Hydrogen energy, 2011, 36: 3206-3214.

[4] Borja O\& Micheal W E, et al. Development of Thermodynamic, Geometric, and Economic Models for Use in the Optimal Synthesis/ Design of a PEM Fuel Cell Cogeneration System for Multi-Unit Residential Applications[J]. Journal of Energy Resources Technology, 2004,126: 21-29 . [5]J.A.Dean. Portland's Handbook of Chemistry [M] Beijing: Science Press, 2003. 